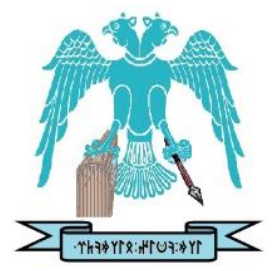

JOURNAL OF ENERGY SYSTEMS

$2021,5(3)$

\title{
Combined cycle gas turbine for combined heat and power production with energy storage by steam methane reforming
}

\author{
Ivan Komarov \\ National Research University "MPEI", 14, Krasnokazarmennaya str., Moscow, Russia, komarovii@mpei.ru \\ Sergei Osipov (1) \\ National Research University "MPEI", 14, Krasnokazarmennaya str., Moscow, Russia, osipovsk@mpei.ru \\ Olga Zlyvko (iD) \\ National Research University "MPEI", 14, Krasnokazarmennaya str., Moscow, Russia, zlyvkoov@mpei.ru \\ Andrey Vegera (D) \\ National Research University "MPEI", 14, Krasnokazarmennaya str., Moscow, Russia, vegeraan@ mpei.ru \\ Vladimir Naumov* (i) \\ National Research University "MPEI", 14, Krasnokazarmennaya str., Moscow, Russia, \\ happyvovanaumov@gmail.com
}

\begin{abstract}
Submitted: 11.05 .2021
Accepted: 06.09 .2021

Published: $\quad 30.09 .2021$

${ }^{\star}$ Corresponding Author: $+8(909) 1526339$

Abstract: The co-generation facilities have maximal thermal efficiency. In the case of the Russian Federation, for the power production industry, the development of the co-generation combined cycle facilities (CCGTCHP) is especially urgent. The CCGT-CHP daily load schedule requires the demand of both electricity and heat, and the heat demand depends only upon the ambient air temperature. The gas turbine power reduction and the subsequent steam turbine power reduction during the electric load drop down are limited by the necessity to maintain the steam flow to district water heater to supply heat power. Methane steam reforming allows the recovery of the excess steam heat in the form of synthetic gas together with the CCGT-CHP electric power reduction. This paper considers three versions of the CCGT-CHP steam use in the Methane reforming: Bleeding steam supply, throttling of the heat recovery steam generator exit steam and the supply of this steam to the steam production in a steam transformer. Steam Methane reforming allows a reduction in the steam turbine supply power of $25 \%$ during the electric system power drop down. In the daytime, during the maximal system load, the produced synthetic gas is used and it is necessary to use the peak load gas turbine, which allows a $23 \%$ electric power increase. Energy storage by steam Methane reforming increases the contribution margin by $2.9 \%$.
\end{abstract}

Keywords: Combined cycle gas turbine, Combined heat and power, Energy storage, Maneuverability, Steam methane reforming.

Cite this paper as:

Komarov, I., Osipov, S., Zlyvko, O., Vegera, A., Naumov, V., Combined cycle gas turbine for combined heat and power production with energy storage by steam methane reforming. Journal of Energy Systems 2021, 5(3): 231-243, DOI: 10.30521/jes.936064

(c) 2021 Published by peer-reviewed open access scientific journal, JES at DergiPark (https://dergipark.org.tr/en/pub/jes)

\begin{tabular}{r|lr|l} 
Nomenclature & & & \\
\hline CC & Combustion chamber & HRSG & Heat recovery steam generator \\
CCGT & Combined cycle gas turbine & LP FWP & Low-pressure feed water pump \\
CHP & Combined heat and power & LPE & Low-pressure economizer \\
CM & Contribution margin & LPS & Low-pressure superheater \\
CP & Condensate pump & LPT & Low-pressure steam turbine \\
DH & District heating & LPV & Low-pressure vaporizer \\
GT & Gas turbine & PHES & Pumped hydroelectric energy storage \\
HP FWP & High-pressure feed water pump & RP & Recirculation pump \\
HPE & High-pressure economizer & SC & Supercharger \\
HPS & High-pressure superheater & SG & Synthetic gas \\
HPT & High-pressure steam turbine & SMR & Steam methane reforming \\
HPV & High-pressure vaporizer & ST & Steam turbine \\
\hline \hline
\end{tabular}




\section{INTRODUCTION}

High-power production in heat supply mode and high fuel consumption efficiency are the specific features of CCGT-CHP [1-3]. The widespread introduction of CCGT-CHP is hampered by their low maneuverability. The daily power delivery schedule requires both electricity and heat, but the heat delivery depends only upon the ambient air temperature. The gas turbine power reduction and the subsequent steam turbine power reduction related to the electric power reduction are limited by the necessity of maintaining the heat supply power. Thus, the development of the heat flow improvements aimed at improved CCGT-CHP maneuverability is a topical task.

The subsequent decompression of the power demand schedule causes large variations in electricity prices in the day-ahead electricity market. During load reduction at night, the day-ahead electricity market index may drop down even to zero [4]. During the periods of low electric power demand, the reasonable solution for a power production company is power reduction to decrease the losses and increase the electricity price. Therefore, it is increasingly important to improve the maneuverability of the facilities including the CCGT-CHP. This problem may be solved by the introduction of highcapacity energy storage systems.

The periods of electric and heat power reductions can be overcome by use of various energy storage methods. The power supply reduction or increase caused by the load drop or increase may be balanced by the introduction of electric energy accumulators [5]. Another method is the application of thermal energy accumulators that supports the heat supply power at varying power production.

The accumulator types are the following: The pumped hydroelectric energy storage (PHES), electrochemical, air, mechanical, hydrogen, etc. [6-9]. The most widespread is now PHES, which provides up to $96 \%$ of energy storage facilities worldwide. The accumulating facilities may have remarkably high generation power, 2820 MW Kanagawa PHES and 1200 MW Zagorsk PHES; some of them have a large storage capacity, $1950 \mathrm{bln} \mathrm{kWh}$ in Zagorsk PHES. The PHES efficiency is approximately $65-85 \%$, and it requires two water storage ponds with a large height difference [10]. This is why a PHES is either constructed near the existing large storage ponds with a height difference or requires artificial pond construction [10]. The electrochemical acid-Lead and Lithium-ion electrochemical accumulators have high transformation efficiency [11], but their storage capacity is low, and they are subject to the self-discharge effect. This effect remarkably reduces the energy capacity during long storage periods, in Lithium-ion accumulators, $5 \%$ in the first 24 hours and a further 1-2\% monthly. The air accumulators are based on the air compression into vessels for the charge and air expansion in turbines for discharge; the alternative method is air discharge into a gas turbine facility. Here, the main shortage is the low efficiency of $30-40 \%$ and the low storage density [10]. Mechanical accumulators use weight-lifting energy or the rotation inertia energy. In these types of storage, efficiency is high, but the energy discharge period is short. One more technology is the hydrogen production in electrolyzers and its use in fuel cells.

The heat accumulator may use steam, hot water, phase transformation, or fillers [12]. The hot water and steam accumulators are based on the heat storage in water. In accumulators based on phase change, the heat is stored in the latent melting heat of a material, usually of different salts. The filler type accumulators store heat in solid materials that fill storage.

Steam Methane reforming (SMR) is a prospective method of load control. Part of the steam does not take part in the steam turbine power production but is supplied to the SMR facility for the synthetic gas (SG) production. The reaction of methane conversion into SG is endothermic, so the heat of the produced gas will be higher than the heat of the supplied gas. The SG that is produced may be stored for a long time without energy losses. In periods of peak power consumption, the synthetic gas may be supplied 
to the CCGT-CHP combustor for the production of heat and electricity. The produced SG has high Hydrogen contents, so its combustion improves the power and efficiency of a CCGT-CHP.

Available published papers do not disclose a CCGT-CHP maneuverability improvement by the integration of hydrogen production from Methane. On the contrary, this technology may be an efficient method for the extension of the CCGT-CHP control range as it allows the employment of steam and a steam turbine power reduction. Therefore, the investigation of SMR integration into CCGT-CHP heat flow and the maneuverability improvement is relevant.

The aim of this paper is the investigation of the use of SMR for energy storage in the CCGT-CHP power plant and its effects on thermodynamic and economic efficiency. The use of steam Methane reforming for accumulating energy in the form of synthetic gas during the energy system drop down mode in the combined cycle gas turbine CHP is considered. The stored synthetic gas is then used to produce additional power during the energy system peak mode. Three versions of SMR integration into CCGTCHP were developed and comparison was made according to the thermodynamic efficiency. The chosen version was then compared based on the contribution margin with CCGT-CHP without energy storage.

\section{CCGT-CHP WITH STEAM METHANE REFORMING ENERGY STORAGE}

The CCGT-CHP with the steam methane reforming facility (Fig. 1) includes the following elements:

The Steam Methane reforming.

The cooled gas turbine.

The steam facility including a twin-circuit steam generator, steam turbine and heat supply heater.

Peak load gas turbine.

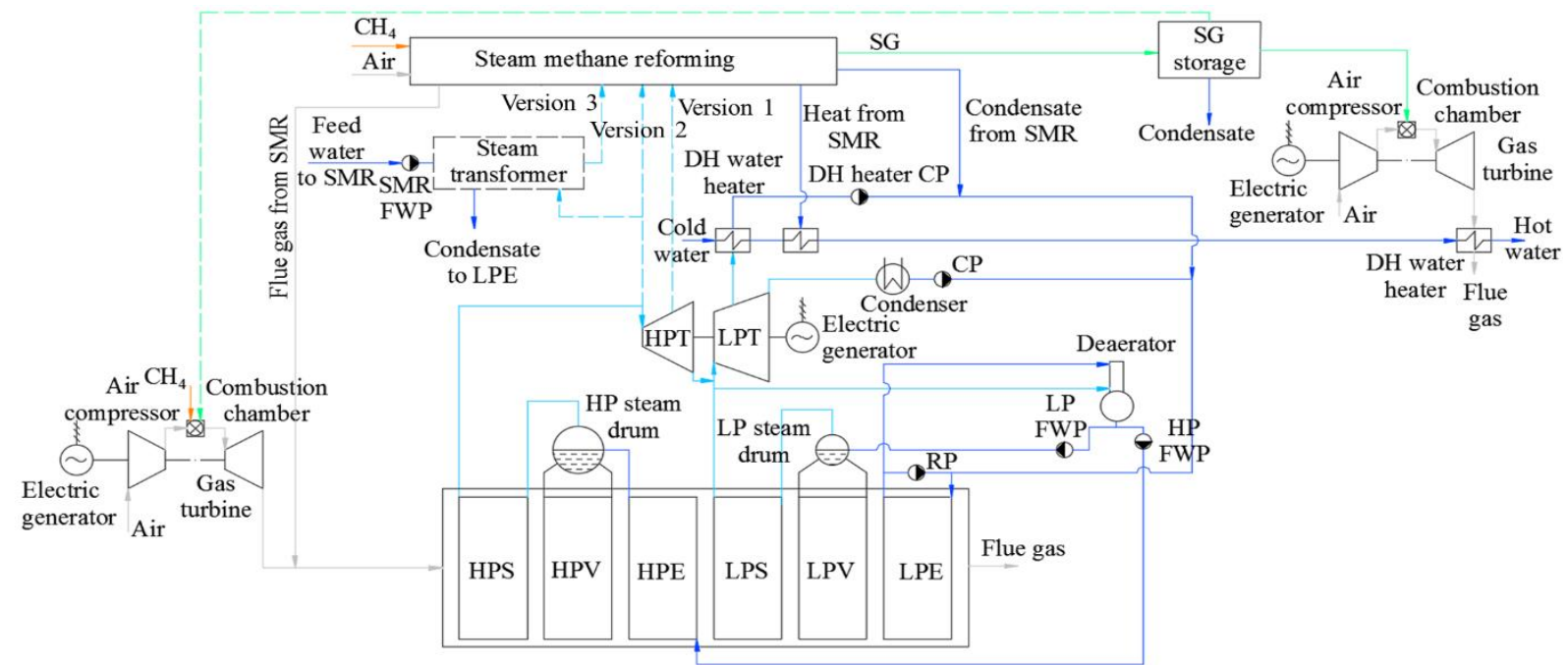

Figure 1. Flow chart of a CCGT-CHP with steam methane reforming and peak load gas turbine facility.

The following CCGT-CHP flow charts were considered, which differ in steam supply for synthetic gas production:

Version 1: Steam bleeding from steam turbine. 
Version 2: High-pressure steam throttling.

Version 3: Steam production in a steam transformer by high-pressure steam.

In gas turbine the ambient air is compressed in an air compressor and supplied to the combustor where it oxidizes fuel. The resulting high-temperature gas expands in the gas turbine and enters the heat recovery steam generator (HRSG) where the heat is transmitted to the recovery steam turbine cycle.

The steam condensate from condenser enters the condensate pump (CP). Then, the condensate is heated in the low-pressure economizer (LPE). Downstream from the LPE, a part of the condensate is supplied to the recirculation pump and enters the LPE to maintain the constant inlet water temperature and prevent low-temperature sulfur corrosion. Then, the condensate enters the deaerator where the steam from the turbine bleeding heats it up to the saturation temperature. After the deaerator feed water splits into two flows, the first flow is supplied to the low-pressure feed water pump (LP FWP), and the second part to the high-pressure feed water pump (HP FWP). The low-pressure water enters the low-pressure drum and the low-pressure vaporizer (LPV). The saturated steam from the low-pressure drum is supplied to the low-pressure superheater (LPS) and to the low-pressure steam turbine (LPT) entrance. The highpressure water from the high-pressure feed water pump enters the economizer where it is heated up nearly to the saturation and then transfers to the high-pressure vaporizer (HPV) and high-pressure superheater (HPS). The high-pressure steam may split into a few flows depending upon the operation mode. In the case of electric power drop in Version 2, high-pressure steam is supplied to the SMR facility. In Version 3, the high-pressure steam enters the steam transformer where it delivers its heat to the water that vaporizes, heats up and enters the SMR facility. The residual steam is mixed with the lowpressure steam and enters the low-pressure steam turbine where it expands down to the condenser pressure. Some of the low-pressure turbine steam is taken to the district water heater, and the condensate pump supplies the produced condensate to the LPE.

The steam Methane reforming inlet flow contents are steam, Methane and air. A part of the Methane is compressed in the supercharger compressor until the reaction pressure is mixed with steam and enters the steam reforming reactor where the flow is heated and the reaction takes place. Another part of the Methane is burned with air to transfer heat to the reforming endothermal reaction. The heating gas that has transferred its heat into the reformer is supplied to the heat recovery steam generator. The synthetic gas produced in the reactor is cooled and supplied to the high-temperature conversion reactor where the exothermic reaction takes place. Then, the gas is cooled and the condensate evacuated. The heat from synthetic gas cooling and the exothermic conversion reaction is transferred to the district heating water.

The produced SG with a high hydrogen content enters the storage where it is cooled, and the condensate is evacuated. At peak power mode, some synthetic gas enters the CCGT-CHP combustor, and the remaining gas enters the peak load gas turbine. The non-cooled peak load gas turbine consists of an air compressor, a combustor, a gas turbine and a district water heater. The atmospheric air is compressed in the air compressor and enters the combustor where it oxidizes SG. The combustion products expand in the gas turbine, and exhaust gas transmits its heat to the district water in the heater.

The simulation was carried out in the Aspen Plus software, which is appropriate for thermal and physicschemical simulation (Fig. 2) [13]. The NIST REFPROP database has the lowest error for determining thermo-physical properties, but it contains limited data on the thermodynamic properties of complex mixtures with high water contents near the saturation line. As a result, the equations of state were considered, which have sufficient accuracy and can be used to determine the properties of complex mixtures in a wide range of temperatures and pressures. The thermo-physical fluid properties were determined using the Peng-Robinson equation of state, as it has one of the highest accuracies [14].

The main parameters for heat flow simulation are summarized in Table 1 [4, 15-22]. The facility heat power is half of the maximum. 
Table 1. Input data for the CCGT-CHP with steam methane reforming and peak load gas turbine facility heat flow analysis.

\begin{tabular}{|c|c|}
\hline Parameter & Value \\
\hline Methane temperature, ${ }^{\circ} \mathrm{C}$ & 15 \\
\hline Methane pressure, $\mathrm{MPa}$ & 0.7 \\
\hline Gas turbine entry temperature, ${ }^{\circ} \mathrm{C}$ & 1700 \\
\hline Gas turbine entry pressure, $\mathrm{MPa}$ & 3 \\
\hline Coolant specific flow, $\%$ & 13.6 \\
\hline Internal turbine efficiency, $\%$ & 90 \\
\hline Internal pump efficiency, $\%$ & 85 \\
\hline Internal compressor efficiency, $\%$ & 88 \\
\hline Mechanical efficiency, \% & 99 \\
\hline Electric motor efficiency, \% & 99 \\
\hline Power generator efficiency, $\%$ & 99 \\
\hline High-pressure steam, MPa & 8 \\
\hline Low-pressure steam, $\mathrm{MPa}$ & 0.8 \\
\hline District heating steam turbine bleeding pressure, $\mathrm{MPa}$ & 0.06 \\
\hline Steam under-heating in superheater, ${ }^{\circ} \mathrm{C}$ & 20 \\
\hline Minimal under-heating in high-pressure vaporizer, ${ }^{\circ} \mathrm{C}$ & 30 \\
\hline Minimal under-heating in low-pressure vaporizer, ${ }^{\circ} \mathrm{C}$ & 10 \\
\hline Steam turbine exit pressure, $\mathrm{kPa}$ & 5 \\
\hline Low-pressure feed water pump exit pressure, MPa & 1 \\
\hline High-pressure feed water pump exit pressure, $\mathrm{MPa}$ & 10 \\
\hline Condensate pump exit pressure, $\mathrm{MPa}$ & 0.8 \\
\hline District heating water heater condensate pump exit pressure, MPa & 0.8 \\
\hline Condensate temperature at the inlet of low-pressure economizer, ${ }^{\circ} \mathrm{C}$ & 60 \\
\hline Deaerator pressure, $\mathrm{MPa}$ & 0.7 \\
\hline Under-heating at low-pressure economizer exit to the saturation temperature, ${ }^{\circ} \mathrm{C}$ & 10 \\
\hline Synthetic gas pressure, MPa & 2 \\
\hline Steam to methane ratio & 5 \\
\hline Reformer exit temperature, ${ }^{\circ} \mathrm{C}$ & 700 \\
\hline Reformer inlet heating gas temperature, ${ }^{\circ} \mathrm{C}$ & 800 \\
\hline Reformer exit heating gas temperature, ${ }^{\circ} \mathrm{C}$ & 400 \\
\hline Synthetic gas temperature at the high-temperature conversion reactor inlet, ${ }^{\circ} \mathrm{C}$ & 450 \\
\hline Synthetic gas temperature at the high-temperature conversion reactor exit, ${ }^{\circ} \mathrm{C}$ & 275 \\
\hline Synthetic gas temperature at the steam methane reforming facility exit, ${ }^{\circ} \mathrm{C}$ & 80 \\
\hline Under-heating in the steam transformer superheater, ${ }^{\circ} \mathrm{C}$ & 20 \\
\hline Pressure of intermediate condenser in steam transformer, $\mathrm{MPa}$ & 2 \\
\hline Pressure of low-pressure condenser in steam transformer, $\mathrm{MPa}$ & 0.8 \\
\hline Super-cooling in the steam transformer bleeding, ${ }^{\circ} \mathrm{C}$ & 10 \\
\hline Condenser cooling temperature at the steam transformer exit, ${ }^{\circ} \mathrm{C}$ & 80 \\
\hline Synthetic gas content in the CCGT-CHP combustor inlet, peak load, \% & 10 \\
\hline Working fluid temperature at the peak load gas turbine inlet, ${ }^{\circ} \mathrm{C}$ & 750 \\
\hline Pressure at the peak load gas turbine inlet, $\mathrm{MPa}$ & 1.45 \\
\hline Exhaust gas temperature after district heating water heater in peak load gas turbine, ${ }^{\circ} \mathrm{C}$ & 90 \\
\hline Natural gas price, $\mathrm{RUB} / \mathrm{kg}$ & 6.48 \\
\hline Natural gas low heating capacity, MJ/kg & 49.157 \\
\hline Electricity price during load dropdown, RUB/MWh & 700 \\
\hline Electricity price during load peak, RUB/MWh & 1700 \\
\hline Exchange rate, RUB/USD & 75 \\
\hline
\end{tabular}




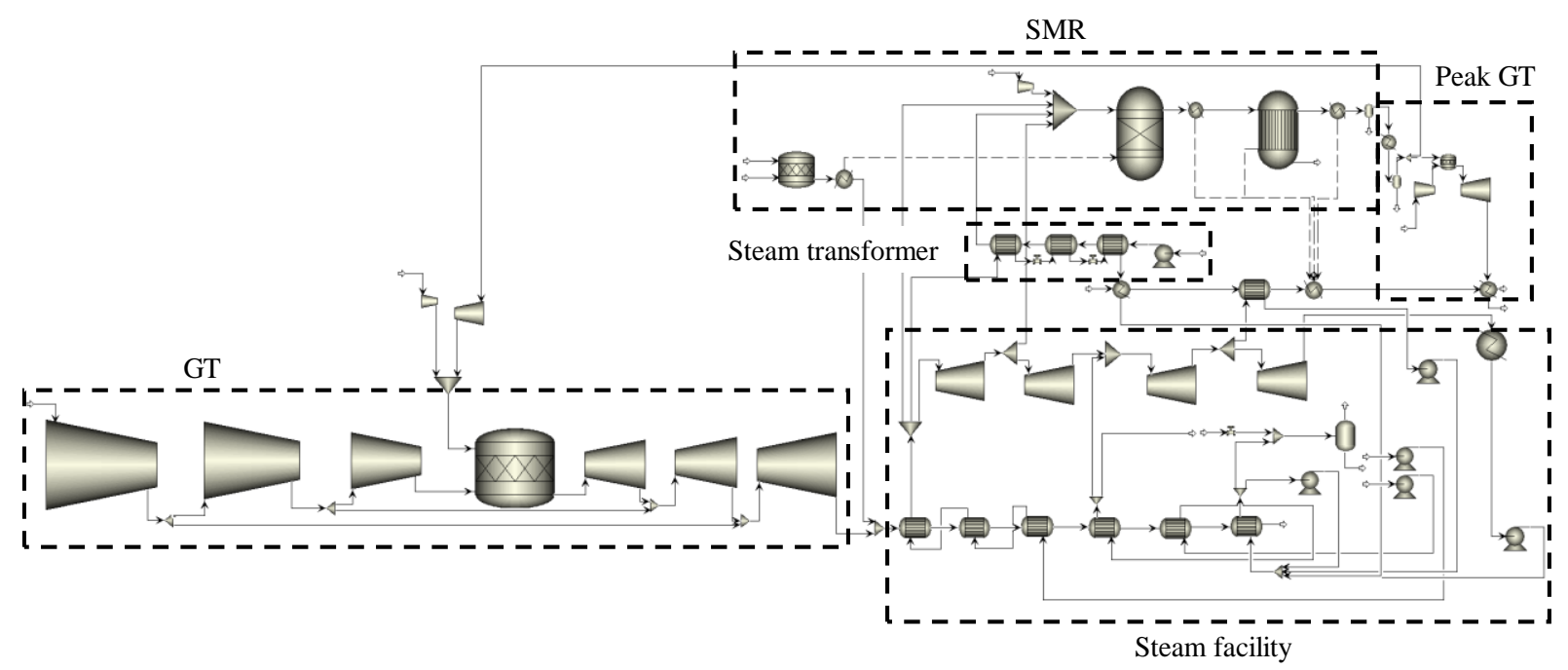

Figure 2. CCGT-CHP with steam methane reforming and peak load gas turbine facility model scheme.

Fig. 3 presents the cooled gas turbine facility flow chart scheme for computer simulation. In the scheme, the compressor is split into three parts, which simulates the gas turbine cooling bleeding [23]. The combustor is supplied with compressor exit air and fuel mixture flows.

The combustor exit gas flow enters the gas turbine that is also shown as split into three parts similar to the compressor model. At low load, the gas turbine air flow is assumed at $70 \%$ of its nominal value.

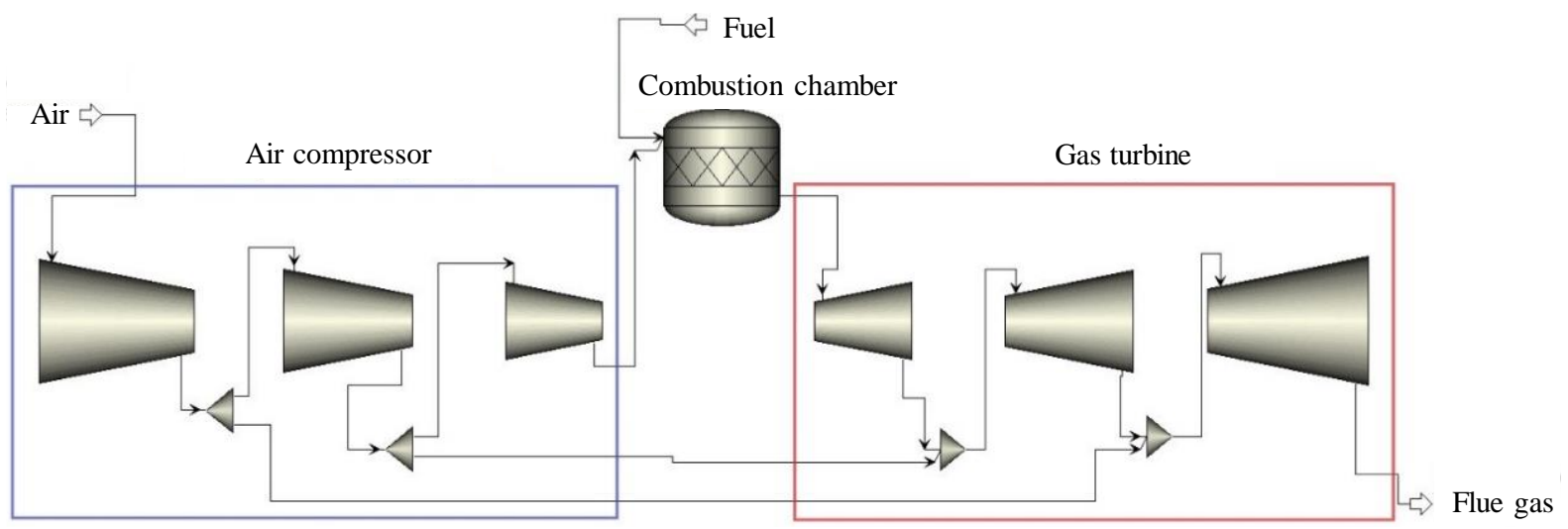

Figure 3. Cooled gas turbine flow chart scheme.

The facility steam compartment has two pressures boiler and a cogeneration steam turbine (Fig. 4). The steam compartment computer simulation model consists of the following elements:

Heat recovery steam generator with steam superheaters, high- and low-pressure vaporizers and highand low-pressure economizers.

Deaerator facility.

Feed water high- and low-pressures pumps, a condensate recirculation pump and a district water heater condensate pump.

Steam turbine compartment with high- and low-pressure turbines and a district water heater. 


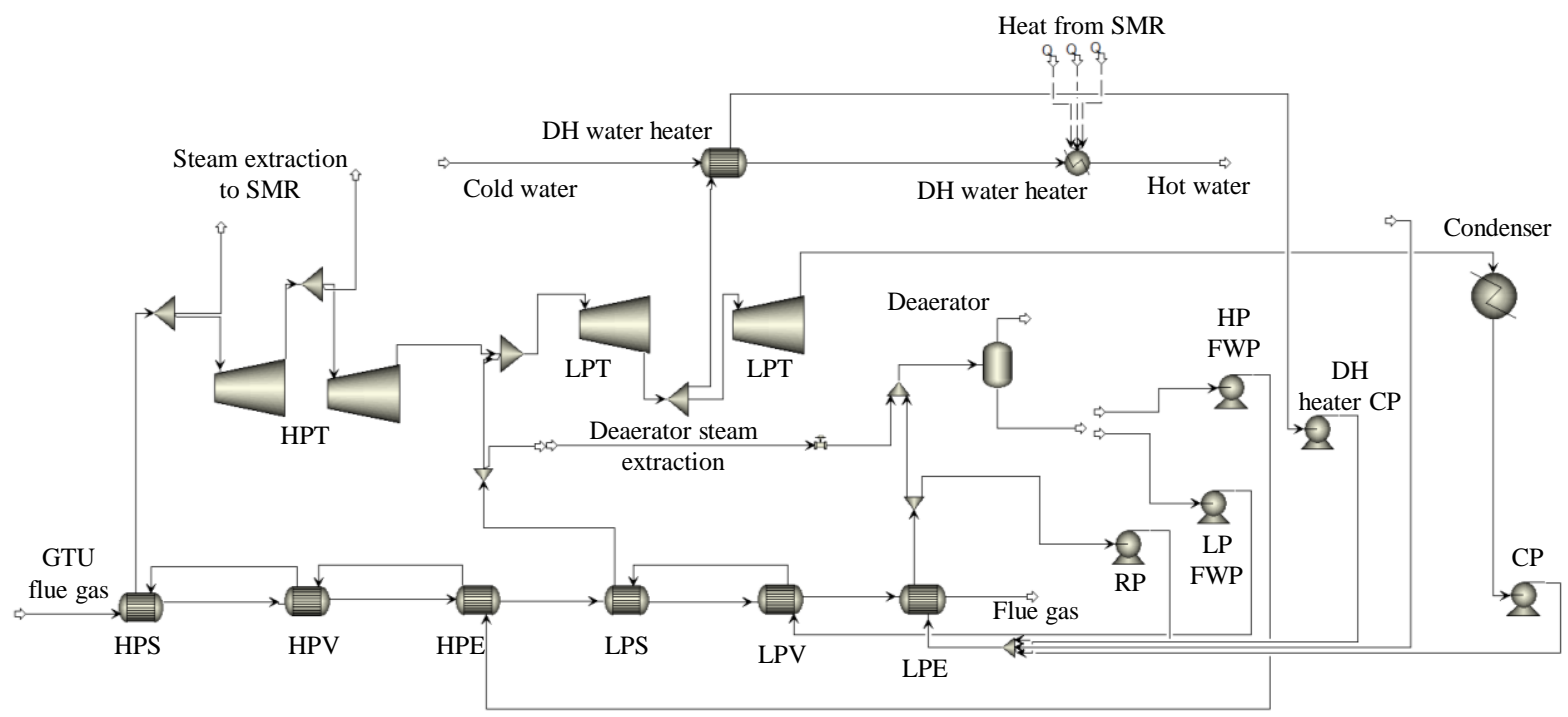

Figure 4. Steam turbine cogeneration compartment simulation flow chart.

The high- and low- pressure steam mass flows were selected on the basis of under-heating on the recovery boiler heating surfaces. The deaerator steam flow heated the exit feed water up to its saturation temperature.

The steam Methane reformer parameters were taken according to the published data [24-26]. The facility consists of a steam reformer and a high-temperature conversion reactor (Fig. 5). It transforms natural gas into the synthetic gas with a high hydrogen content. The steam reforming reactor model in Aspen Plus consists of a combustor, a heat exchanger and a model of a Gibbs chemical reactor (RGibbs). The reactor model calculates the products contents on the basis of Gibbs free energy minimum. The reactor exit product contents are nearly balanced, so a Gibbs reactor application is approved (the balanced contents are seen in industrial steam reforming facilities [27]). The reformer inlet mixture has a high steam content, which allows high hydrogen contents. The methane is pressurized up to the reaction pressure with a supercharger. The modeling of a high-temperature shift reactor involved the chemical reactor simulator REquil that calculates the balanced reaction product. Then, the gas is cooled and condensate evacuated.

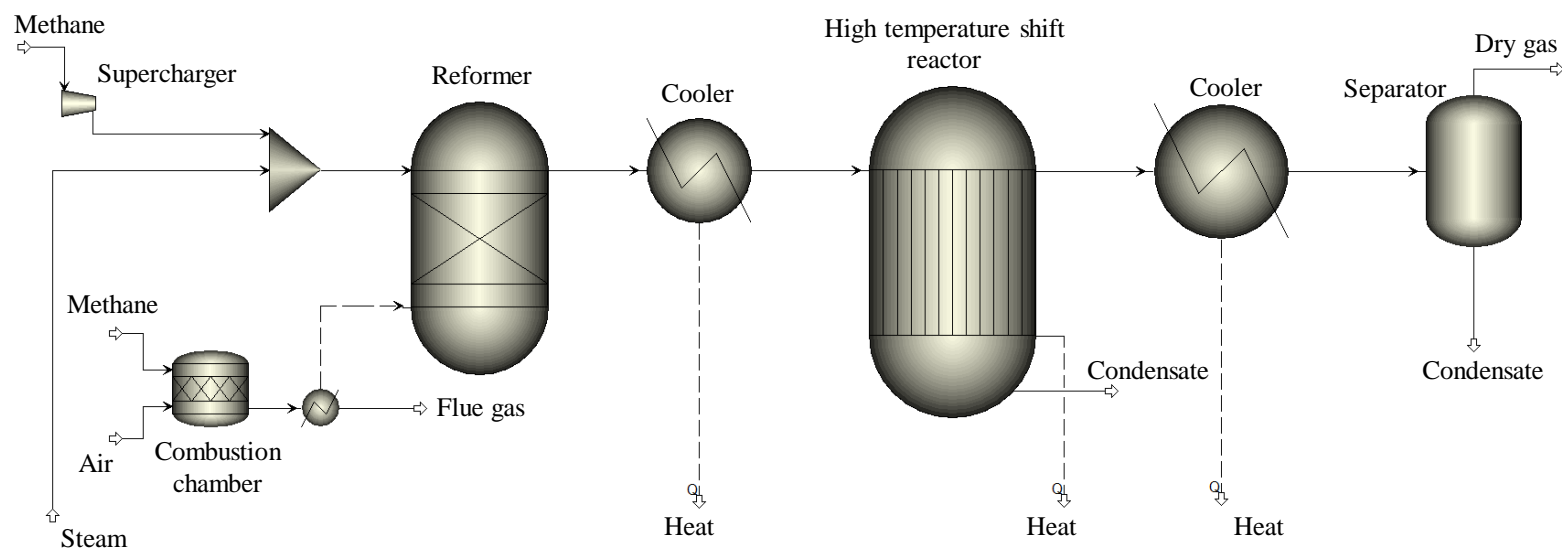

Figure 5. Steam conversion model scheme.

The steam transformer of Version 3 (Fig. 6) consists of the following:

High-pressure steam superheater where the primary high-pressure steam from the recovery boiler heats the steam for methane conversion.

High-pressure vaporizer where the heating steam is condensed and the heated water evaporated. 
Intermediate pressure condenser where the condensate enters from the high-pressure vaporizer.

Bleeding cooler where the low-pressure condensate is cooled, and the heat is transmitted to the water for steam conversion.

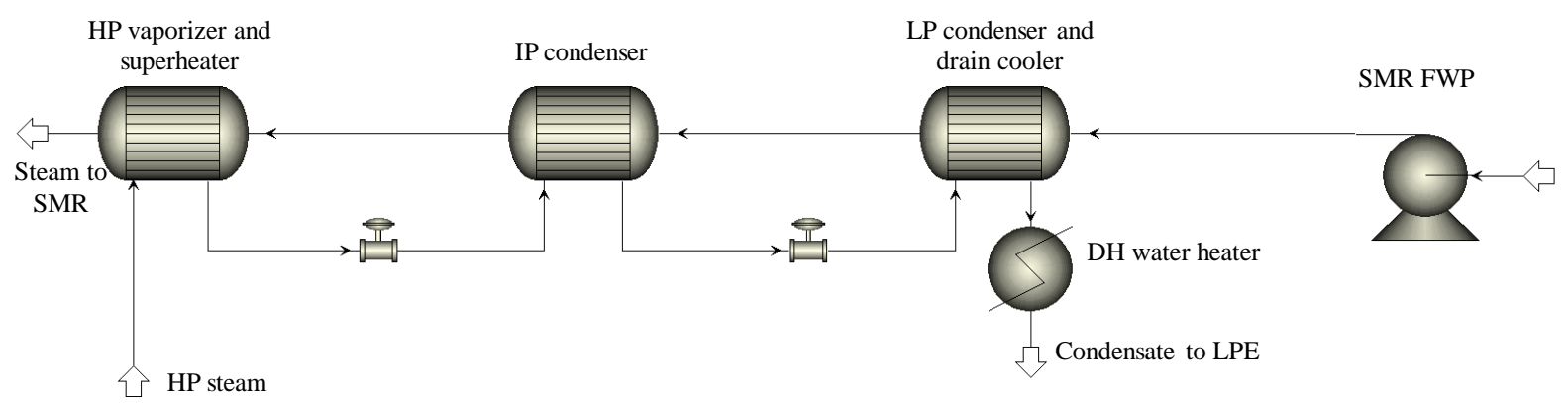

Figure 6. Steam transformer model scheme

During the peak load period, $10 \%$ of synthetic gas fuel mass flow is supplied to the CCGT-CHP combustor, and its remaining flow feeds the peak load gas turbine (Fig. 7). The peak load gas turbine is non-cooled. The exhaust gas heat is recovered in the district water heater.

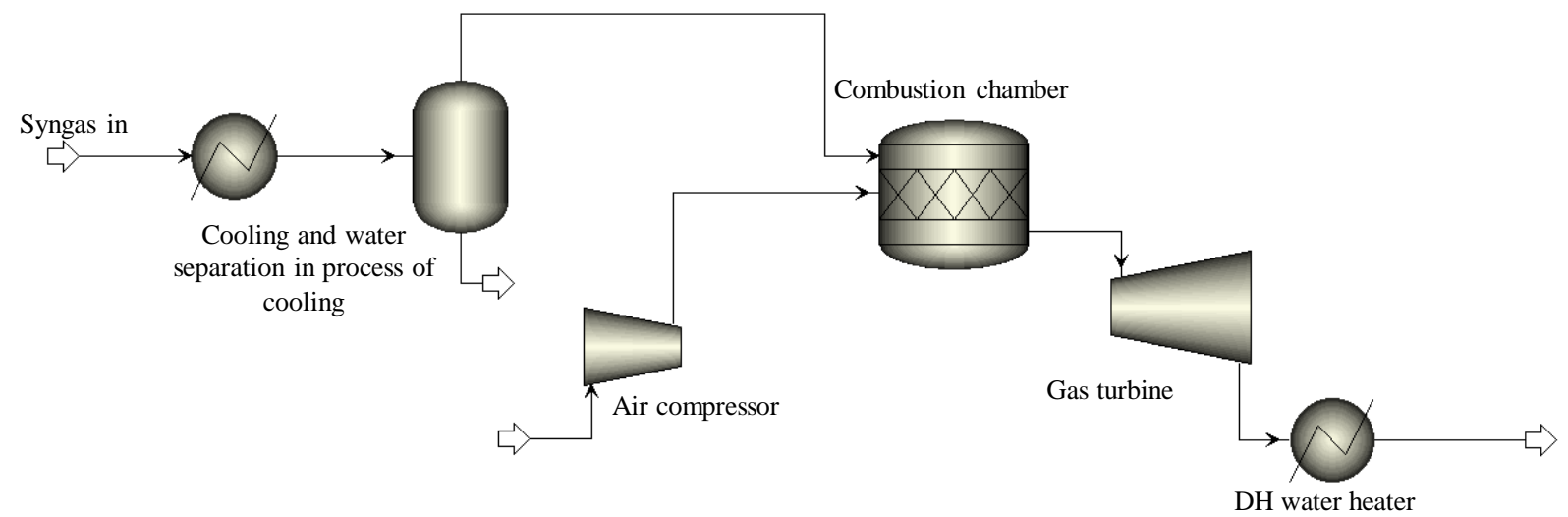

Figure 7. Peak load gas turbine facility scheme

The facility thermal power is assumed constant at the level of half of the maximum. The facility efficiency is calculated with the fuel low heating capacity.

The net efficiency of the installation for the generation of electrical energy $\eta_{\text {elec }}$ was calculated by the physical method in accordance with Eq. (1).

$$
\begin{aligned}
& \eta_{\text {elec_eff }}=\frac{\left(N_{\mathrm{GT}} \eta_{\text {mech }}-\frac{N_{\mathrm{C}}}{\eta_{\mathrm{mech}}}\right) \eta_{\mathrm{eg}}+\left(N_{\mathrm{HPT}}+N_{\mathrm{LPT}}\right) \eta_{\text {mech }} \eta_{\text {eg }}-}{\left(B_{\mathrm{CC} \_ \text {CCGT }}+B_{\mathrm{SMR}}+B_{\text {CC_SMR }}\right) Q_{\mathrm{LHV}}-Q_{t}}
\end{aligned}
$$

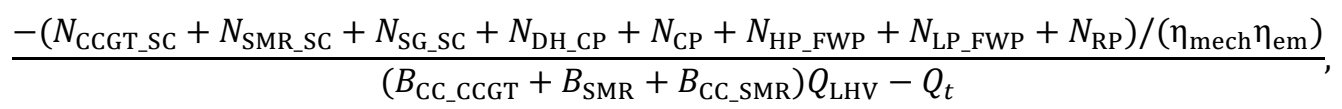

where $N_{\mathrm{GT}}$-gas turbine power, MW; $N_{\mathrm{C}}$-air compressor power, MW; $N_{\mathrm{HPT}}$-high-pressure steam turbine power, MW; $N_{\mathrm{LPT}}-$ low-pressure steam turbine power, MW; $N_{\text {CCGT_SC }}$ - supercharger power for methane delivery to CCGT, MW; $N_{\text {SMR_SC }}$ - supercharger power for methane delivery to SMR facility, $\mathrm{MW} ; N_{\mathrm{SG}_{-} \mathrm{SC}}$ - supercharger power for synthetic gas delivery to $\mathrm{CCGT}, \mathrm{MW} ; N_{\mathrm{DH}} \mathrm{CP}-$ district heating water heater condensate pump power, $\mathrm{MW} ; N_{\mathrm{CP}}$-steam cycle condensate pump power, $\mathrm{MW} ; N_{\mathrm{HP} \text { _FWP }}$ high-pressure feed water pump power, MW; $N_{\text {LP_FWP }}-$ low-pressure feed water pump power, MW; $N_{\mathrm{RP}}$-recirculation water pump power, $\mathrm{MW} ; B_{\mathrm{CC} \_ \text {CCGT }}$ CCGT combustion chamber methane consumption, $\mathrm{kg} / \mathrm{s} ; B_{\mathrm{SMR}}-$ methane consumption for reforming, $\mathrm{kg} / \mathrm{s} ; B_{\mathrm{CC} \_\mathrm{MR}}$-reformer combustion 
chamber methane consumption, $\mathrm{kg} / \mathrm{s} ; Q_{\mathrm{LHV}}$ - low heating value of methane, $\mathrm{MJ} / \mathrm{kg} ; Q_{\mathrm{t}}$ - heat power, MWt; $\eta_{\text {mech }}-$ mechanical efficiency, \%; $\eta_{\mathrm{eg}}$ - electric generator efficiency, $\% ; \eta_{\mathrm{em}}$ - electric motor efficiency, \%.

According to Eq. (2), the indicator of the fuel efficiency $\eta_{\text {fuel_eff }}$ was calculated, which, in contrast to the net efficiency for the generation of electrical energy, considers the heat of the synthetic gas as a product of the facility.

$$
\begin{aligned}
& \eta_{\text {fuel_eff }}=\frac{\left(N_{\text {GT }} \eta_{\text {mech }}-\frac{N_{\mathrm{C}}}{\eta_{\text {mech }}}\right) \eta_{\text {eg }}+\left(N_{\text {HPT }}+N_{\text {LPT }}\right) \eta_{\text {mech }} \eta_{\text {eg }}+}{\left(B_{\text {CC_CCGT }}+B_{\text {SMR }}+B_{\text {CC_SMR }}\right) Q_{\text {LHV }}+Q_{\text {SG_LHV }_{\text {L }} B_{\text {SG }}}} \\
& \frac{+Q_{\mathrm{SG}_{-} \mathrm{LHV}} B_{\mathrm{SG}_{\mathrm{S}} \mathrm{SMR}}+Q_{t}-}{\left(B_{\mathrm{CC} \_\mathrm{CCGT}}+B_{\mathrm{SMR}}+B_{\mathrm{CC}_{-} \mathrm{SMR}}\right) \mathrm{Q}_{\mathrm{LHV}}+Q_{\mathrm{SG}_{-} \mathrm{LHV}} B_{\mathrm{SG}}}
\end{aligned}
$$

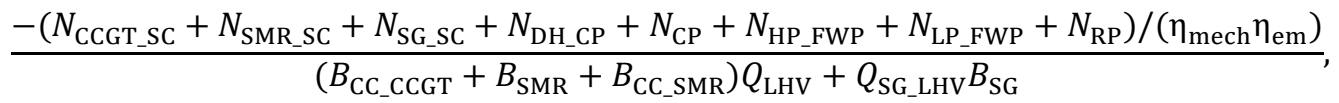

where $Q_{\text {SG_LHV }}$-lower heating value of synthetic gas, MJ $/ \mathrm{kg} ; B_{\mathrm{SG} \_ \text {SMR }}$-synthetic gas generation in SMR facility, $\mathrm{kg} / \mathrm{s} ; B_{\mathrm{SG}}$ - synthetic gas consumption, $\mathrm{kg} / \mathrm{s}$.

The energy storage financial effect was assessed with the contribution margin index, which is the difference between the product selling income and the variable expenses related to the production [28]. In the case of CHP, the products are heat and thermal energies, and the variable expenses are fuel cost and water preparation expenses, water purchase, treatment chemicals, etc. The thermal energy produced is the same at all loads, and the main part of the variable expenses is related to the fuel purchase, so the contribution margin index CM may be calculated with Eq. (3).

$$
C M=t^{\text {peak }}\left(P_{\text {elec }}^{\text {peak }} N^{\text {peak }}-P_{\text {fuel }} B^{\text {peak }}\right)+t^{\text {drop }}\left(P_{\text {elec }}^{\text {drop }} N^{\text {drop }}-P_{\text {fuel }} B^{\text {drop }}\right),
$$

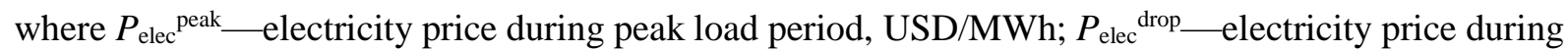

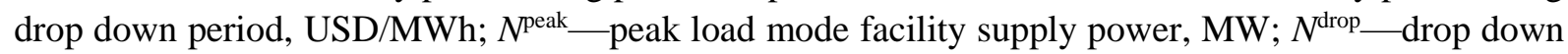

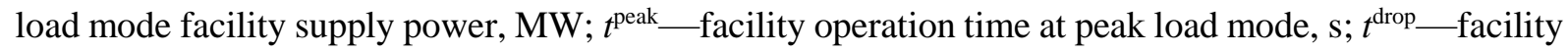
operation time at drop down load mode, $\mathrm{s} ; P_{\text {fuel }}$ fuel price, USD $/ \mathrm{kg} ; B^{\text {peak }}$ —peak load mode fuel

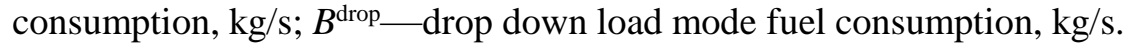

The electricity price is taken according to the data by Trading System Administrator of Wholesale Electricity Market Transactions for the price zone 1 [4]. The described method allows the assessment of the CCGT-CHP parameters with integrated methane steam conversion, its thermal efficiency and the financial effect of its introduction.

\section{RESULTS}

The calculation of the CCGT-CHP parameters during the load drop down period shows the steam turbine power reduction (Fig. 8). The power distribution is due to the multi-pressure recovery boiler-specific features where the lower pressure circuits always produce smaller steam mass flow, so the main steam turbine power is produced by high-pressure steam. Therefore, the remarkable reduction in steam turbine power is reached only by the use of high-pressure steam for methane reforming. 


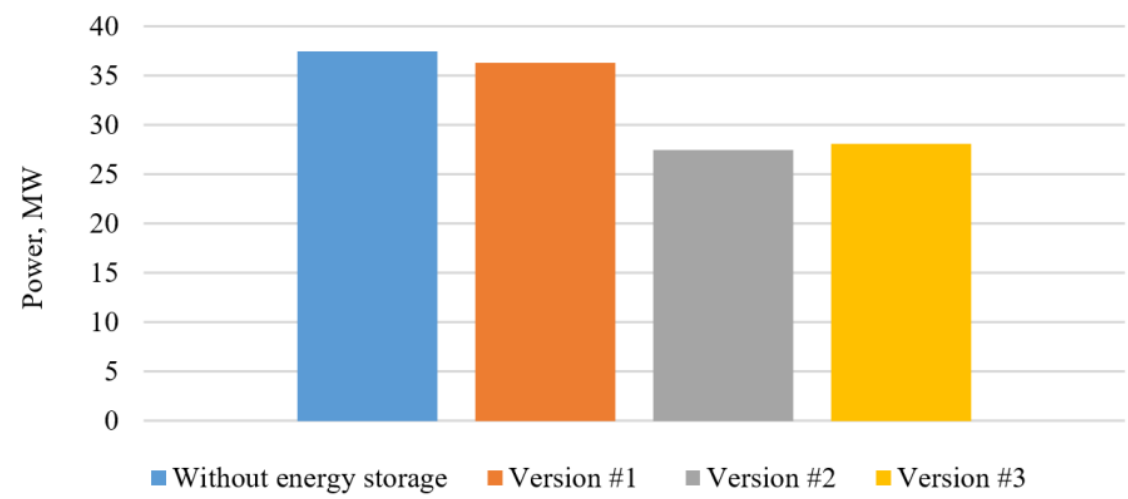

Figure 8. Steam turbine power during the supply power drop down.

CCGT-CHP analysis results (Table 2) show that the high-pressure steam throttling (Version 2) for the methane steam conversion allows the maximal reduction in the CCGT-CHP electric power during the load drop down period (Fig. 9). The most efficient is the steam supply for methane conversion from the steam turbine bleeding (Version 1). Version 3 involves the supply of high-pressure steam in the steam transformer which allows an electric power reduction as with the high-pressure steam throttling (Version 2), but Version 3 is more efficient. The higher power production during peak load periods is provided by the synthetic gas addition to the fuel mixture, which increases the larger steam content in the gas turbine inlet flow and its power increase. In addition, the steam turbine peak power is higher due to the condensing mode turbine operation. This is possible due to the heat load transition to the peak load gas turbine district heating water heater.

The Version 3 CCGT-CHP with a steam transformer allows a remarkable reduction in the steam turbine power at smaller fuel efficiency reduction than in Versions 1 and 2. Therefore, Version 3 with a peak load gas turbine is further considered. The power of the CCGT-CHP with peak load gas turbine at different operation modes is shown in Fig. 10. The peak power operation fuel efficiency is $67.03 \%$ due to the heat recovery in the peak load gas turbine district heating water heater. At the load drop down of $25 \%$, the steam turbine power reduction does not considerably influence the facility power. Nevertheless, the steam application in the SMR facility is followed by a remarkable storage of synthetic gas. This gas supply to the CCGT-CHP and peak load gas turbine allows a peak load power increase of $23 \%$. Thus, the SMR technology allows small power reduction at the load drop down and remarkable power increase at the peak loads.

Table 2. Parameters of CCGT-CHP with synthetic gas energy storage at different operation modes.

\begin{tabular}{llccccc}
\hline \multicolumn{1}{c}{ Parameter } & Mode & $\begin{array}{c}\text { Electric } \\
\text { power, MWe }\end{array}$ & $\begin{array}{c}\text { Heat power, } \\
\text { MWt }\end{array}$ & $\begin{array}{c}\text { Methane } \\
\text { consumption, kg/s }\end{array}$ & $\begin{array}{c}\eta_{\text {elec_eff }} \% \\
\%\end{array}$ & $\begin{array}{c}\eta_{\text {fuel_eff }} \\
\%\end{array}$ \\
\hline CCGT-CHP without & drop & 140.8 & 51.8 & 4.80 & 74.9 & 80.3 \\
energy storage & peak & 204.0 & 51.8 & 6.85 & 70.2 & 74.7 \\
CCGT-CHP Version 1 & drop & 138.9 & 51.8 & 8.55 & 36.9 & 76.3 \\
& peak & 212.2 & 0 & 6.53 & 61.7 & 61.7 \\
CCGT-CHP Version 2 & drop & 129.9 & 51.9 & 9.50 & 30.7 & 75.5 \\
& peak & 212.4 & 0 & 6.55 & 61.7 & 61.7 \\
CCGT-CHP Version 3 & drop & 130.8 & 51.9 & 8.04 & 37.3 & 76.1 \\
& peak & 212.4 & 0 & 6.55 & 61.7 & 61.7 \\
\hline
\end{tabular}




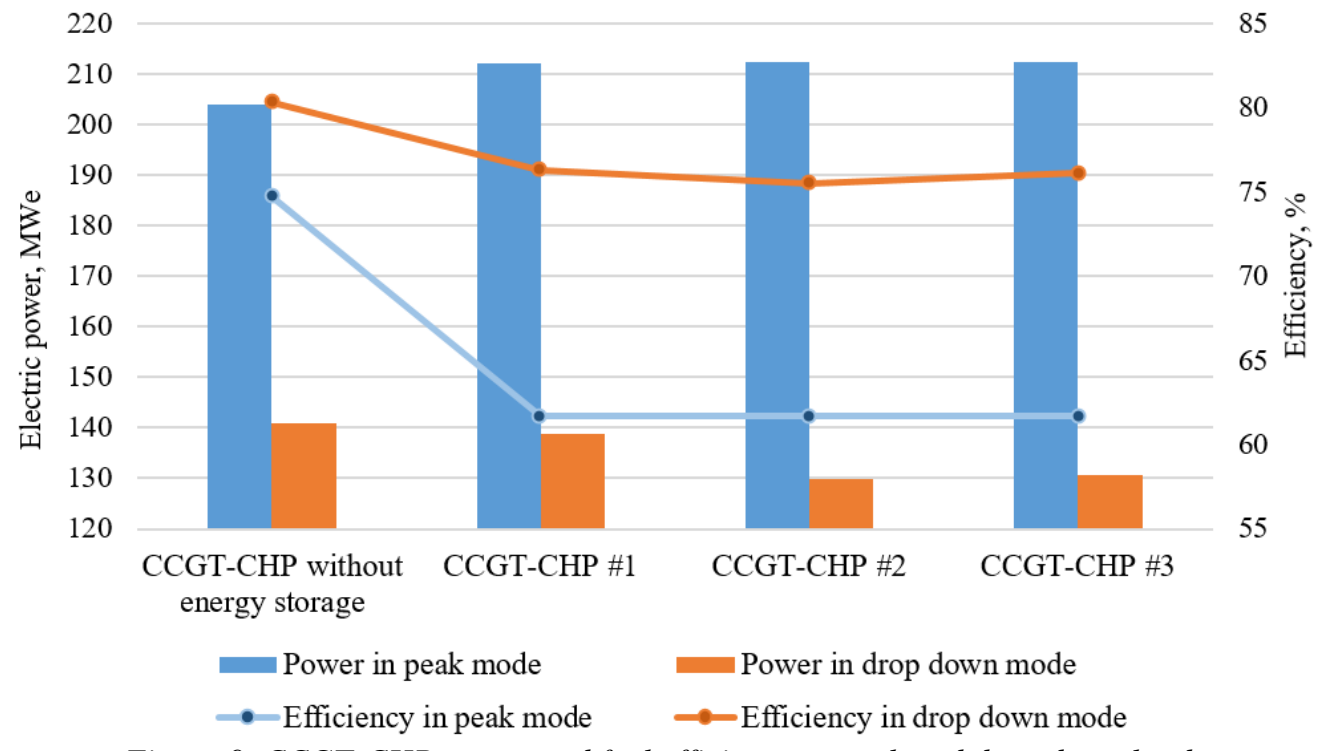

Figure 9. CCGT-CHP power and fuel efficiency at peak and drop down loads.

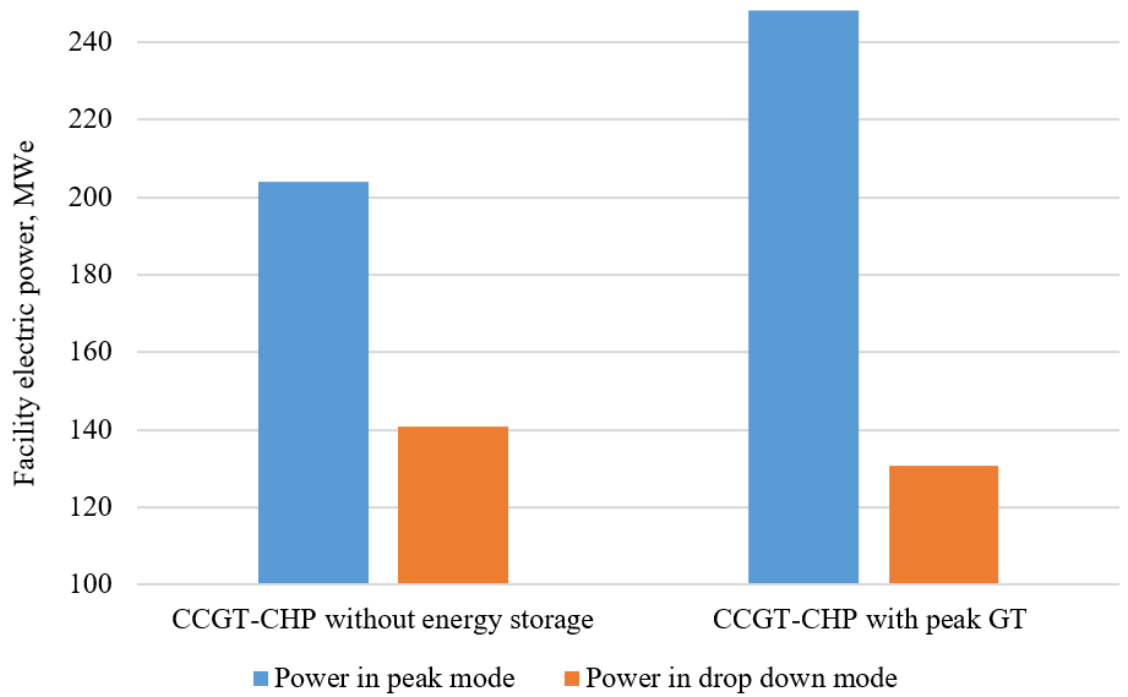

Figure 10. CCGT-CHP facility power without and with energy storage and peak load gas turbine at peak and drop down electric loads.

The financial effect from the introduction of energy storage with SMR in CCGT-CHP was calculated with the contribution margin criteria. The calculation results summarized in Table 3 show that Version 3 energy storage with SMR allows a contribution margin increase of $2.6 \%$.

Table 3. Parameters of CCGT-CHP versions with and without energy storage.

\begin{tabular}{lcccc}
\hline \multirow{2}{*}{\multicolumn{1}{c}{ Parameter }} & \multicolumn{3}{c}{ GTCC-CHP } & GTCC-CHP with SMR Version 3 \\
\cline { 2 - 6 } & drop & peak & drop & peak \\
\hline Electric power, MWe & 140.8 & 201.8 & 130.8 & 248.3 \\
Methane consumption, $\mathrm{kg} / \mathrm{s}$ & 4.80 & 6.85 & 8.04 & 6.55 \\
Methane price, USD/kg & 0.879 & & & \\
Electricity price, USD/MWh & 9.33 & 22.67 & 9.33 & 22.67 \\
Operation period, h & 3 & 3.07 & 3 & 3.07 \\
Electricity selling income, USD & \multicolumn{1}{c}{17999.7} & & 20957.0 & \\
Fuel cost, USD & 11211.3 & & 13995.0 & \\
Contribution margin, heat supply not considered, USD & 6788.4 & & 6962.0 & \\
\hline
\end{tabular}


This is related to the lower power production during the electricity consumption drop down periods and the higher production during the peak power periods with high prices for the supplied electricity.

\section{CONCLUSIONS}

The largest electric power reduction by energy storage with the methane steam conversion is reached by use of high-pressure steam.

The use of steam production with the steam transformer for the methane steam conversion from highpressure steam allows a reduction in steam turbine power of $25.0 \%$, which is lower than the power reduction by the high-pressure steam throttling to the conversion, 26.6\%, but allows higher fuel efficiency at the load drop down $(76.1 \mathrm{vs.} 75.5 \%)$. The minimal reduction in the steam turbine delivered power of $3.2 \%$ was seen at the use of steam bleeding.

The introduction of energy storage reduces the CCGT-CHP nominal load fuel efficiency from 74.7 to $61.7 \%$, which is due to the steam turbine condensing mode operation. In the load drop down mode, the smallest reduction in CCGT-CHP fuel efficiency from 80.3 to $76.3 \%$ was seen during the use of bleeding steam. The largest reduction in fuel efficiency from 80.3 to $75.5 \%$ was seen at throttling high-pressure steam for the steam methane reforming supply; in the case of steam use in the steam transformer, fuel efficiency is reduced to $76.1 \%$.

The use of the produced synthetic gas in the peak load gas turbine increases the delivered electric power by $23.0 \%$ together with the fuel efficiency reduction from 74.7 to $67.0 \%$. The use of the district water heater downstream from the peak load gas turbine allows the steam turbine condensing mode operation, which also increases the delivered power.

Energy storage using high-pressure steam in a steam transformer for the production of steam supplied to the methane steam conversion increases the contribution margin by 173.6 USD or $2.6 \%$.

\section{Acknowledgment}

This study conducted by Moscow Power Engineering Institute was financially supported by the Ministry of Science and Higher Education of the Russian Federation (Project No. FSWF-2020-0020).

\section{REFERENCES}

[1] Zaryankin, A, Mager, A, Rogalev, A, Komarov, I. Superpowerful combined cycle power units with one gas turbine. WIT Transactions on Ecology and the Environment 2014; 190(1): 251-260. DOI: 10.2495/EQ140251.

[2] Rogalev, N, Prokhorov, V, Rogalev, A, Komarov, I, Kindra, V. Steam boilers' advanced constructive solutions for the ultra-supercritical power plants. International Journal of Applied Engineering Research 2016; 11(18): 9297-9306.

[3] Lisin, E, Rogalev, A, Strielkowski, W, Komarov, I. Sustainable modernization of the Russian power utilities industry. Sustainability 2015; 7(9): 11378-11400. DOI: 10.3390/su70911378.

[4] Internet Web-Site: Hub indices: Trading System Administrator of Wholesale Electricity Market Transactions, https://www.atsenergo.ru/results/rsv/hubs/hubs?zone=1.

[5] Komarnicki, P. Energy storage systems: Power grid and energy market use cases. Archives of Electrical Engineering 2016; 65(3): 495-511. DOI: 10.1515/aee-2016-0036.

[6] Guney, MS, Tepe, Y. Classification and assessment of energy storage systems. Renewable and Sustainable Energy Reviews 2017; 75: 1187-1197. DOI: 10.1016/j.rser.2016.11.102.

[7] Alami AH. Mechanical energy storage for renewable and sustainable energy resources. Heidelberg, GERMANY: Springer International Publishing, 2020. 
[8] Sinyugin V, Magruk V, Rodionov V. Hydro-storage power plants in modern electric power industry. Moscow, RUSSIA: Litres, 2018.

[9] Myasina MA, Kosmynina NM. Study of the modes of the Zagorskaya PHES. In: 23-rd International Symposium of Students and Young Scientists Problems of Geology and Subsurface Development; 8-12 April 2019: TPU Publishing House, Tomsk, Russia, pp. 240-241.

[10] Frate, GF, Ferrari, L, Desideri, U. Energy storage for grid-scale applications: Technology review and economic feasibility analysis. Renewable Energy 2021; 163: 1754-1772. DOI: 10.1016/j.renene.2020.10.070.

[11] Ceran, B. A comparative analysis of energy storage technologies. Polityka Energetyczna - Energy Policy Journal 2018; 21(3): 97-110. DOI: 10.24425/124498.

[12] Alva, G, Lin, Y, Fang, G. An overview of thermal energy storage systems. Energy 2018; 144: 341-378. DOI: 10.1016/j.energy.2017.12.037.

[13] Rogalev, A, Komarov, I, Kindra, V, Zlyvko, O. Entrepreneurial assessment of sustainable development technologies for power energy sector. Entrepreneurship and Sustainability Issues 2018; 6(1): 429-445. DOI: 10.9770/jesi.2018.6.1(26).

[14] Rogalev, A, Grigoriev, E, Kindra, V and Rogalev, N. Thermodynamic optimization and equipment development for a high efficient fossil fuel power plant with zero emissions. Journal of Cleaner Production 2019; 236: 117592. DOI: 10.1016/j.jclepro.2019.07.067.

[15] Valamin, AY, Kultyshev, AY, Bilan, VN, Goldberg, AA, Sakhnin, YA, Shekhter, MV, Aguilera, HCP, Stepanov, MY, Shibaev, TL, Polyaeva, YN. The cogeneration steam turbine of the T-63/76-8.8 type for a series of PGU-300 combined cycle power plants. Thermal Engineering 2012; 59(12): 883-892. DOI: $10.1134 / \mathrm{S} 0040601512120099$.

[16] Karpunin, AP. Study of the influence of the parameters of GTU and CCGT on their characteristics based on the technique with detailed taking into account of losses from cooling in a gas turbine. $\mathrm{PhD}$, National Research University, Moscow, Russia, 2016.

[17] Trukhnii, AD. Combined-cycle plants of power plants. Moscow, RUSSIA: MPEI, 2013.

[18] Romano, MC, Cassotti, EN, Chiesa, P, Meyer, J, Mastin, J. Application of the sorption enhanced-steam reforming process in combined cycle-based power plants. Energy Procedia 2011; 4: 1125-1132. DOI: 10.1016/j.egypro.2011.01.164.

[19] Carapellucci, R, Giordano, L. Upgrading existing gas-steam combined cycle power plants through steam injection and methane steam reforming. Energy 2019; 173: 229-243. DOI: 10.1016/j.energy.2019.02.046.

[20] Lozza, G, Chiesa, P. Natural gas decarbonization to reduce $\mathrm{CO}_{2}$ emission from combined cycles: Part I Partial oxidation. J. Eng. Gas Turbines Power 2002; 124 (1): 82-88.

[21] Lozza, G, Chiesa, P. Natural gas decarbonization to reduce $\mathrm{CO}_{2}$ emission from combined cycles: Part IISteam-methane reforming. J. Eng. Gas Turbines Power 2002; 124 (1): 89-95.

[22] Internet Web-Site: Official exchange rates: Bank of Russia, https://cbr.ru/currency_base/dynamics, Feb 2021.

[23] Canière, H, Willockx, A, Dick, E, De Paepe, M. Raising cycle efficiency by intercooling in air-cooled gas turbines. Applied Thermal Engineering 2006; 26 (16): 1780-1787. DOI: 10.1016/j.applthermaleng.2006.02.008.

[24] Fahim MA, Alsahhaf TA, Elkilani A. Hydrogen Production. In: Fahim MA, Alsahhaf TA, Elkilani A, editors. Fundamentals of Petroleum Refining. Oxford, UK: Elsevier, 2010. pp. 285-302.

[25] Equipment design and cost estimation for small modular biomass systems, synthesis gas cleanup, and oxygen separation equipment. Task 1: Cost estimates of small modular systems. Final report. San Francisco, USA: National Renewable Energy Laboratory, 2006.

[26] Internet Web-Site: H2A: Hydrogen analysis production models: National Renewable Energy Laboratory, https://www.nrel.gov/hydrogen/h2a-production-models.html.

[27] Corradetti, A, Desideri, U. Analysis of gas-steam combined cycles with natural gas reforming and $\mathrm{CO}_{2}$ capture. Journal of Engineering for Gas Turbines and Power 2005; 127(3): 545-552. DOI: 10.1115/1.1850941.

[28] Alivanova, SV, Kurennaya, VV. Marginal analysis as the effective method of choice of administrative decisions. Scientific Journal of KubSAU 2012; 80(06): 0801206015. 